Island Studies Journal, Vol. 11, No. 2, 2016, pp. 485-504

\title{
Decolonizing Creole on the Mauritius islands: Creative practices in Mauritian Creole
}

\author{
Gitanjali Pyndiah \\ Centre for Cultural Studies, Goldsmiths University of London, U.K. \\ g_pyndiah@yahoo.fr
}

\begin{abstract}
Many Caribbean and Indian Ocean islands have a common history of French and British colonization, where a Creole language developed from the contact of different colonial and African/ Indian languages. In the process, African languages died, making place for a language which retained close lexical links to the colonizer's tongue. This paper presents the case of Mauritian Creole, a language that emerged out of a colonial context and which is now the mother tongue of $70 \%$ of Mauritians, across different ethnic and linguistic backgrounds. It pinpoints the residual colonial ideologies in the language and looks at some creative practices, focusing on its oral and scribal aspects, to formulate a 'decolonial aesthetics' (Mignolo, 2009). In stressing the séga angazé (protest songs) and poetry in Mauritian Creole in the history of resistance to colonization, it argues that the language is, potentially, a carrier of decolonial knowledges.
\end{abstract}

Keywords: creolization, decolonial knowledges, Indian Ocean islands, language resistance, Mauritian Creole, Mauritius.

(C) 2016 - Institute of Island Studies, University of Prince Edward Island, Canada.

\section{Introduction}

The poem below is written in an orthography of Mauritian Creole which, as a creative practice, subverts the official 'harmonized orthography' (Hookoomsing, 2004), GrafiLarmoni, to retain certain oral tonalities of the language, in its scribal aspects. It, however, does not undermine the determination of postcolonial linguists, writers, activists and advocates of literacy acquisition in the mother tongue who have militated for fifty years to bring official recognition to the language through codification.

Kaya, or Joseph Reginald Topize, was a Mauritian singer, well known for initiating seggae, a fusion between séga and reggae. On 21 February 1999, he was arrested for smoking marijuana at a concert, which was organized to promote the decriminalization of cannabis. He was found dead in police custody two days later. An autopsy has shown that he was brutalized, with 32 injuries, two of them fatal, on his body. His death provoked protests and riots on the island. This poem was written on the 17 th anniversary of his death. 


\section{G. Pyndiah}

\section{Mauritian Creole}

Kayaa! wee Kaya!

Sammem Kaya

kiti sânt: fãm dân-zil

fãm ki partoupartou ...

Kaya

kiti fer gâgn kâyakâya

kanli sânt trânkiltrânkil

ekdonn lespwar zjot tou

Kaya

ki débat dân marénwar

kont enn pouvwar stéril

ki-ânter vré rezonmân dan trou

Kaya

baté a mor par lapolis grânnwar

kinn détrir lapei frazil

Ânba enn larkânsyel flou

\section{English translation}

Kaya! yes Kaya!

The same Kaya

who sang: island women

who are all over the world ...

Kaya

Who made us feel giddy

when he sang his slow music

and gave us all hope

Kaya

struggling in the darkness

against a sterile power

which buries true reason

Kaya

beaten to death by an arrogant police

which destroyed a fragile peace

in the blurred rainbow nation

(Gitanjali Pyndiah)

Mauritian Creole is the mother tongue of $70 \%$ of the population of Mauritius, an Indian Ocean archipelago, and remains the main language of communication across the islands (Mooneeram, 2009). Depending on the urban or rural nature of the setting, interaction occurs in Mauritian Creole or in Bhojpuri (Asgarally, 2015). However, in relation to informal writing (based on interaction on social media, for example, which denotes a younger demographic), Mauritian Creole remains the most popular language (Hookoomsingh, 2004). This is despite the colonial residue of English as the official language of parliament, law, administration, and academia and French as the first language in which most Mauritians acquire literacy and the language mostly used in the media. Mauritius has a population of under 1.3 million inhabitants who also speak Hindi, Marathi, Tamul, Telegu, Gujerati, Urdu, Arabic, Hakka, Cantonese and Mandarin and practice different religions (Hinduism, Islam, Roman Catholicism, and to a lesser extent Buddhism, Sikhism, Protestantism, and Adventism). Most ancestral languages play an important role in the cultural, religious and ritualistic set up of the different communities on the island, such as religious ceremonies, rites of passage and social practices. 
Recently, a standardized Mauritian Creole has been prescribed in certain schools, based on mother tongue literacy programs, which aim to facilitate the acquisition of literacy skills in the learner's mother tongue. This paper looks at how Mauritian Creole emerged out of an oppressive colonial context and has been used as support to colonial ideologies on the island while, paradoxically, being suppressed to an inferior status relative to the French language. It focuses on the language as the mother tongue of a multiethnic population and selects certain creative practices in Mauritian Creole which articulate the possibilities of a decolonial aesthetics and epistemology (Mignolo, 2009).

\section{The Creole language in colonial Mauritius}

Mauritius is mostly referred to and perceived as a singular island in the collective memory of mainland Mauritians (Collen, 2007). However, the independent state of Mauritius consists of islands and archipelagos in the Indian Ocean (IO), namely the main island of Mauritius, Rodrigues, Agaléga, Tromelin, St Brandon islands and the Chagos archipelago including Diego Garcia (disputes over the sovereignty of Tromelin and the Chagos archipelago have been an ongoing political and legal issue since independence) (Figure 1).

\section{Figure 1: Locator Map of the Republic of Mauritius (Claimed islands in white font).}

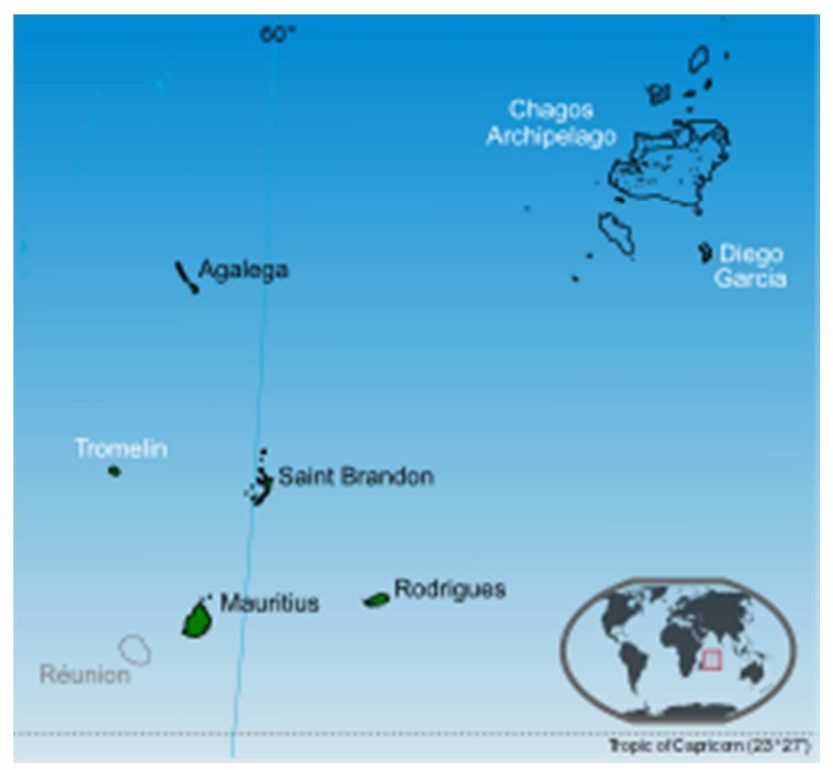

Source: (O) 2016 Wikipedia.

The islands were uninhabited before European ventures in the Indian Ocean, and have a history of 330 years of slavery, indentured labour as well as free migration from Africa, India and China during Dutch (1638-1710), French (1710-1810) and British (1810-1968) colonization. The history of human contact on the islands is thus born at the inter-related junction of capitalism and colonialism (Mintz, 1986). Slavery, as a system of capitalist exploitation of people, from the eastern coasts of East Africa, Madagascar (and India to a smaller extent) began with Dutch settlement, on the main island of Mauritius, and was 


\section{G. Pyndiah}

persevered by the French East India Company for the supply of labour to sugar plantation economies. The oligarchy was made up of colonials, plantation owners and workers (mainly from Brittany in France) and their descendants born on the island, later categorized as FrancoMauritians. Consequently, the different African and Indian languages brought by slaves in conjunction with the French language which were most probably dialects from Brittany (Chaudenson \& Mufwene, 2001), provided the initial interface that impelled the development of a creole language on the islands. The language evolved for more than a century and, before the Indian Ocean islands passed to British hands in 1810, by the end of the Napoleonic wars, a French Creole was already well established.

In linguistic terminologies, Mauritian Creole and French have been in a diglossic relationship since the early eighteenth century. Diglossia is described as the linguistic situation of a community where two or more varieties of the same language are of unequal status, with a high and a low variety (Fergusson, 1959, quoted in Mooneeram, 2009). According to Mooneeram (2009, p. 34),

A stable diglossia seems to coincide with the colonial order when a European language, the high variety is used in official and political fields and when the language of lower prestige, the low variety, is left to casual everyday conversation and popular songs intended for light entertainment, a situation which initiates and perpetuates prejudice against the low language.

French still remains the mother tongue of most of the Franco Mauritians and the offspring of biracial relationships, the 'coloured' or 'milat' (mulatto) population, and later the rising urban bourgeoisie of Indo (of Indian origin)-Mauritians (Asgarally, 2015, p. 82). In French Mauritius, when the ratio of French settlers to African slaves and biracial populations began to preoccupy officials, the term 'Creole' was defined in marriage legislations to represent an emerging mixed population (TJC, 2011, p. 107). However, since the twentieth century, 'Creoles' and 'ti Créoles' (creoles of the rural working areas) in Mauritius have referred to people with African phenotype whose mother tongue is the Creole language (Boswell, 2006, p. 47). Skin colour and language varietal differentiation, together with class differentiation, mark a conspicuous divide between the Franco-Mauritians and the coloured population. Similar to the Antilles, the 'milat' adopts the colonial language, which in practical terms, represents "the key that can open doors which were still barred to him fifty years ago" (Fanon, 2008, p. 25). Frantz Fanon's 1952 psychoanalysis of the linguistic condition in Martinique echoes a similar situation in Mauritius. "To speak means to be in a position to use a certain syntax, to grasp the morphology of this or that language, but it means above all to assume a culture, to support the weight of a civilization" (Fanon, 2008, p. 8). The middle class of the Antilles only speak Creole to their servants and, in school,

The children of Martinique are taught to scorn the dialect. Some families completely forbid the use of Creole, and mothers ridicule their children for using it (Fanon, 2008, p. 10). 
The taboo around Creole languages is a reflection of an inferiority complex, visible in the attachment of the colonized for the colonial language (Fanon, 2008). Ngũgĩ wa Thiong'o (1986, p. 11), like Fanon, takes a psychological framework to analyse the impact of colonization on ancestral languages in Kenya. Similar to the experience of creole languages in the Antilles and in Mauritius, Ngũgĩ recalls the "humiliating experiences" of being caught speaking Gikuyu in Kenyan colonial schools, where English was rewarded and native languages demonized. For Quijano (2008) and other Latin American scholars, the denigration of non-colonial languages represents colonial dominance at a systemic and epistemic level.

The abolition of slavery would dramatically change the island's dynamics. After the Napoleonic Wars, British sovereignty was established in the Indian Ocean, but under the negotiated 1815 Treaty of Paris, the French plantocracy gained rights of occupation and to maintain their laws and customs on the Mauritian islands. The Roman Catholic Church and other institutions would sanction the French Civil Code, French language, and French culture. By the 1830s, in preparation for the 1833 Slavery Abolition Act, a different kind of exploitation would be devised in the form of indentured labour from British India. Half a million Indians, many of whom were peasants from rural India (Bihar, Andhra Pradesh, Mumbai, Tamil Naidu and their peripheries), were initially bound by a five-year contract to replace slave labour on the island. Many free Indians and Chinese also migrated to Mauritius and joined the social category of the rising non-white bourgeoisie. Depending on the regions where the Indians and Chinese came from, several dialects and established languages were spoken (Tamul, Bengali, Hindi, Urdu, Bhojpuri, Marathi, and Telugou by Indians and Cantonese, Hakka, and Mandarin by Chinese). The growing indentured population, under British administration and French occupation (1810-1968), contributed to a shift in power dynamics and consequently changed the linguistic, social and cultural setup. The great majority of Indian immigrants came from Bihar and spoke Bhojpuri, the predominant language of the Mauritian countryside at the end of the nineteenth century (Ramyead, 1985). The "gravitational pull from India is strongly felt in Mauritius: it possesses a much stronger Indian flavour than any society in the New World" (Eriksen, 1992, paragraph 7). After India and Nepal, Mauritius is the country with the third-largest community of Hindus and has, as a result, witnessed a process of creolization (Hannerz, 1992; Chaudenson \& Mufwene, 2001) that has differed from those of the Caribbean islands, producing a multiethnic and multilingual society, by the end of British colonialism, that is perhaps most closely mirrored by the multiculturality of Trinidad and Tobago (Munasinghe, 2001), than other Caribbean locations.

Commonalities between the creolized islands of the Atlantic and the Indian oceans have often been established (Bernabé et al., 1990, p. 894). However, this solidarity is not part of the narrative of language politics in Mauritius. The literary and political development of Mauritian Creole and creoleness in the Indian Ocean also differ from, for example, the Martinican experience, despite historical similarities with the Caribbean. Various linguistic ideologies competing around Mauritian Creole, especially from ancestral languages from India and colonial languages (both French and English), change the dynamics of creoleness and creole language on the Indian Ocean islands. The notion of creoleness for descendants of French, African, Malagasy, and Indian origin prior to Indenture was re-dynamized by the drastic changes in the country's rural demographics (Hazareesingh, 1977), with the confined mobility of the Indian community on the sugar cane plantations. The formation of villages in the rural areas, where a growing Indian population settled, developed into spaces where different 


\section{G. Pyndiah}

communities would maintain their mother tongues, religions, customs and rituals. Bhojpuri was widely spoken in the rural areas in the second half of the nineteenth century by the different linguistic communities that came from India as well as people of Chinese descent and the coloured population, especially on the plantations.

However, the Bhojpuri language underwent a decline with the expansion of Creole among the younger generation, spread through schooling, socialization and urban-rural mobility (Eisenlohr, 2006). Many 'colonial' schools, mostly run by missionaries used French or Creole as the language of instruction, refusing to teach children of Indian origin in their vernacular languages. Consequently, speaking Bhojpuri became firmly associated with rural life and agriculture, while creole was associated with lower governmental offices and schooling (Eisenlohr, 2006, p. 208). The imposition of urban French and Creole on rural cultural lives was one of the reasons why Hindu activists and nationalists supported a linguistic ideology and propelled Bhojpuri to a higher status through "hinduizing and hindiizing" (Eisenlohr, 2006, p. 219). Bhojpuri, like Creole, has a 'motya' (rough) variety and a refined one, reinforcing the class divide between Indian immigrants and bringing about the decline in the use of the language. This brought an irreversibility to Creole as the main language of communication across communities of Indian, Chinese, African, French and mixed ethnicities, who communicate in Mauritian Creole despite their different classes, religions, cultural practices and linguistic ancestries. A continuum of accents in the creole languages matured in a diverse manner in the urban and semi-urban areas with scattered pockets in the rural areas. By the mid-twentieth century, a significant shift to Creole, with varieties in accents, pitches and stresses in the language, was already in place.

\section{Colonial ideologies, decolonization, and Creole}

In 1968, when Mauritius gained independence, a Franco-Mauritian economic elite shared centre stage with a non-white (mostly Hindu) rising political and economic elite. A sharing of power was devised to promote a mixed-capitalist economy, giving way to a 'consociational democracy' (Boudet \& Peghini, 2008) and later a 'comprador bourgeoisie' (Amin, 1994) made up of Mauritian elites of French, Indian, Chinese and the 'coloured' population who shared economic interests. Direct colonial rule was certainly over, but an epistemic colonialism remained in the daily life of the former colony, sustained somewhat by a neocolonial bourgeoisie, as witnessed in many postcolonial states (Ngũgĩ, 1986). After some 50 years of decolonizing, Mauritius remains nested in colonial symbols, representations, geographies, historiographies and epistemologies (Boudet \& Peghini, 2008; Edensor \& Kothari, 2005; Eriksen, 1998, Forest, 2011; Kothari \& Wilkinson, 2010; Selvon, 2005; Salverda, 2011). The persistence of colonial epistemologies and historiographies in new nations has been articulated by many, with reference to anti-colonial and supposedly 'post' colonial situations (Fanon, 2008; Grosfuguel, 2011; Guha, 1998; Said, 1993). 
Decolonization can be discussed in three overlapping phases. The first period of the decolonization process is 'primary resistance' (Said, 1993, p. 95) in which anti-colonial movements were legitimate tools to resist the violence of colonialism and to recover appropriated territory. The second period is 'ideological resistance', which according to Said (1993) represents a set of efforts towards the restoration of a sense of humanhood, dignity and freedom against oppression under the colonial enterprise and culminates in the implementation of the nation-state. However, decolonization is never complete with nationhood (Fanon, 1963, Anderson 1983) as "bourgeois nationalism is the form which colonized societies enter [Western notion of] modernity" (Lowe \& Lloyd, 1997). The notion of the postcolonial which was established as a "model of power defined by binary opposition and sovereign domination" has now been contested, as the contemporary political and economic world encompass "more diffuse, pervasive, subtle, sinister and hegemonic" forms of power (Bignall, 2011, p. 2). Hence, decolonization is an ongoing process of resistance against the residues of colonialism such as the economic system of capitalism and post-independence "coloniality of power" (Quijano, 2008, p. 197), defined as encompassing a set of practices of deconstruction, construction and reconstruction at the level of epistemology, historiography and ideology. Furthermore, practices also include "self-concept and attitudes of being, relating and belonging" and "non-imperial modes of action and relation" (Bignall, 2011, p. 2). Decolonization critically tackles the residues of colonization and post-independence systems of governance, inherited from colonial structures.

On 12 September 1969, only one year after Mauritius negotiated independence from the UK (under Harold Wilson's government), a group of young militants protested against the official visit of Princess Alexandra and her husband, businessman Angus Ogilvy, a financial supporter of the plantocracy on the island (Selvon, 2005). Influenced by the rise of student mobilization across Europe and liberation/decolonization movements around the Global South, a few engaged students at the University of Mauritius formed a collective (Club de Étudiants Mauriciens) and organized a street protest against the neocolonial setup of independent Mauritius. They expressed their concern about the residual inequalities perpetuated by the inherited economic structure and denounced the conservatism and ethnic politics of the Labour Party and its inherited Western notion of development, modernization and state-building sustained by colonial apparatuses, attitudes and practices (Selvon, 2005, pp. 208-209). Their revolutionary ideas clashed with the decolonizing programs of the new government, based on Fabian socialism and set on sustaining a capitalist economy, and shifting power to the non-white, non-urban population. Furthermore, the immediate postindependence uprising occurred between an urban intellectual elite which harboured a revolutionary politics and an intelligentsia with political connections to the rural demographics, determined to take over the political control of the country and relieve the people of colonial rule. 


\section{G. Pyndiah}

Dev Virahsawmy, a linguist of Indian origin, who was amongst the founders of the Club des Étudiants Mauriciens, brought attention to Mauritian Creole as a potential denominator of national and cultural cohesion after his studies in linguistics at the University of Edinburgh. Virahsawmy insisted on referring to Mauritian Creole as 'Morisiê' to "invalidate the association between the language and the Creole ethnic group and to include everyone on the basis of nationality rather than ethnicity, furthering the point that Mauritius had a national language to fall back on in the challenging task of nation-building" (Mooneeram, 2009, p. 34). Nation building and decolonizing knowledge-making through language have been the project of other postcolonial thinkers. Both Edward Said (1993) and Ngũgĩ wa Thiong'o (1986) pinpoint the relevance of non-imperialist languages in the process of cultural resistance to colonization. Said (1993, p. 97) proposes restoring the imprisoned nation to itself through national languages for a practice of a national culture which produces narratives of communal memory through slogans, pamphlets, newspapers, folk tales and heroes, epic poetry, novels and drama, even if those solidarities are essentially grounded in an imagined basis (Anderson, 1983). The use of Mauritian Creole was initially a tool for nationalist aspiration as well as propaganda, similar to the cultural movement of creole nationalisms (very often initiated by an urban intellectual elite) which occurred in certain Caribbean island societies such as St Lucia and Haiti, which has the world's largest Creole-speaking population, and the Seychelles islands in the Indian Ocean. Other islands witnessed pro-Creole movements such as Oktob 77 in Réunion Island, a French department like Martinique, which, however, died out in the 1970s (St-Hilaire, 2011), despite 91\% of its population speaking creole. The exclusive use of French in schools was "an instrument for the decreolization and deculturation of the island" (Armand, 1993, quoted in St-Hilaire, 2011).

The Creole language flourished in Mauritius prior to language politics across class, ethnic, and religious backgrounds. It did not, however, overpower Bhojpuri and other Indolanguages, as can be witnessed in the rural areas, similar to how African languages were kept alive by the peasantry and oral practices. For Ngũgĩ (1986, p. 23), despite the perpetuation of colonial ideologies and epistemologies,

African languages refused to die. They would not simply go the way of Latin to become the fossils for linguistic archaeology to dig up, classify, and argue about.

Creole languages are also, by default, not monolingual, and in most creole societies, code switching is the norm. Other inherited European languages (or in this case, ancestral languages from India) share the linguistic repertoire of the speaker, with the result that other commonly spoken languages are not discarded by Creole societies. Derrida (1998, p. 36), at a colloquium, entitled 'Echoes from Elsewhere', hosted by Edouard Glissant at the Louisiana State University, explains that the originary uniqueness and the possessive attribute of one mother tongue concentrates on the characteristic of the language as the 'only one' (like a mother). It can be reductive as the need to be possessive (i.e. 'my' mother tongue) also implies a fear of losing or a loss of it. In relation to his personal experience of speaking mainly in French, his language of 'adoption' as an Algerian Jew, he believes that nobody has exclusive possession of a language, least of all the colonial master who pretends "historically, through the rape of a cultural usurpation, which means always essentially colonial, to appropriate it in order to impose it as “his own'” (Derrida, 1998, p. 23). As Spivak (2016, paragraph 4) puts it, 
Decolonizing Creole on the Mauritius islands: Creative practices in Mauritian Creole

Whole groups get excluded because a certain kind of dominant discourse is established. He [Derrida] also said a very powerful thing about African orality: they could remember seven generations back; we've lost that capacity. There, 'writing' takes place on the psychic material called 'memory'.

\section{This paper}

This paper primarily discusses certain creative practices which problematize the loss of oral practices through the codification of the Creole language.

In 2011, Mauritian Creole was standardized and codified, which brought it to official recognition and formal introduction in the educational system (Hookoomsingh, 2004). Five main stages (Harmon, 2011) can be traced in the evolution of Mauritian Creole from around the time of independence until the language was eventually codified: 1) 1960s: nationalism around language as a marker of national unity; 2) 1970s: class struggle and trade unionism militating for the language to be employed for popular education and adult literacy; 3 ) late 1970s: golden era when cultural militants use Creole to revitalize music, theatre and the arts; 4) late 1990s: an AfroKreol movement gains momentum after the death of Kaya, regrouping Creoles who appropriate the language as ancestral identity; and 5) the codification of Mauritian Creole in 2004. In linguistic terminologies, Mauritian Creole has moved from a pidgin, a contact language which emerged from the forced slave experience with colonial culture in the eighteenth century, to codification.

The Grafi-Larmoni orthography is a 'harmonized' orthography (not 'uniformized', thereby allowing the language and orthography to evolve within a flexible and dynamic system) which facilitates a standardized way of writing the language (Hookoomsingh, 2004, p. 39). Other orthographies had been proposed by Virahsawmy, Ledikasyon Pu Travayer (an organisation actively involved in the standardization of Mauritian Creole for literary and literacy purposes), and other language activists since the 1970s. A consensus was reached in 2004, after the support of the government to finally recognize Mauritian Creole. The accepted orthography is close to the French language and orthography, based on the "practical consideration of a consensus [which] outweigh the symbolic ones of perpetually safeguarding the identity of Mauritian Creole as separate from French" (Mooneeram, 2009, p. 43). The practicality of a Creole orthography that is close to French was argued to be better suited for educational purposes, to help Mauritians acquire literacy in their mother tongue (Hookoomsingh, 2004). This 'harmonized' orthography, however, reduces the spectrum of phonetic varieties of the Creole language and the flexibility for incorporating into writing the different accents, pitches, stresses and rhythms from the influence of other languages. The team working on the accepted orthography, acknowledges that "a certain amount of redundancy is necessary" (Mooneeram, 2009, p. 39). 


\section{G. Pyndiah}

This article looks at one creative practice in Mauritian Creole, the séga angazé, which consists of political songs composed in the Creole language. The séga evolved in the slave camps in French Mauritius, as songs of resistance, resilience and humanhood (Harmon, 2015). This article demonstrates two facets of the appropriation of the séga: as neocolonial entertainment and as decolonial aesthetics. Two examples of decolonial aesthetics are also expanded here: the role of women in both the séga narrative and in song-writing, and the 'vulgarity' associated with Mauritian Creole. The séga has been studied as a folklore dance and song with a "creole narrative grammar" (Haring, 2009). The present article reads the séga as a form of creative practice in Mauritian Creole, consisting of 'everyday practices' of resistance (De Certeau, 1988; Lugones, 2003), which take the form of creative and inventive expressions. It carries the histories of resistance to colonial oppression as well as stories of "slave 'personhood', in a world where slave humanity [was] constantly challenged and denied" (Capuano, 2003, p. 96). Slaves' songs are "the articulate message of the slave to the world" (Du Bois, 1903, p. xx) and slaves "were sustained and healed and nurtured by the translation of their experience into art, above all in the music" (Morisson, 1993), as a form of story-telling. Accounts of slaves in Mauritius, by European visitors (in 1801, for instance) depict them as "great compositors, able to improvise songs on the spot about anything that vividly strikes their imagination," spending their Sundays dancing "to forget the injustice which was their lot" (Selvon, 2005, p. 186).

After the abolition of slavery and under English rule, the séga was marginalized and denigrated by the coloured population and the Roman Catholic Church. It continues, however, to be performed by freed slaves in the privacy of their courtyard. From the 1950s, the séga is popularized and commercialized by Franco-Mauritians and the coloured population, through the media, as folklore and symbol of 'local flavours', disregarding any traditional songs and dance brought by Indians and Chinese. In 1964, during La Nuit du Séga (The Séga night), organized by the Ministry of Industry, Commerce and Tourism, to promote a 'Mauritian' folklore and propel the séga 'nationally' (the independent nation does not exist yet), Tifrer, a séga singer of Malagasy origin, would be crowned the 'King of Séga'. Joseph Ravaton was nicknamed Tifrer (meaning little brother) by rural Creole communities and people of Indian descent who approved his musical talent when he performed in their communities (Pyndiah, 1978). Tifrer was also known for entertaining, in certain Franco-Mauritians' private evenings and hunting parties (Paniken, 2011 in Assonne, 2013). While the nickname 'Tifrer' denotes kinship and solidarity, the 'King', who remains in a financially precarious situation until his death, is elevated and legitimated as symbol of a francophile appreciation of creoleness. By promoting Tifrer as the King, and so as unique and above other séga artists, the uniqueness of choice of the francophile bourgeoisie is paradoxically promoted, dismissing the philosophy of resistance against French colonialism and humanhood inherent in the slaves' séga. 
A certain sexism and erotic 'vulgarity' (Paniken, 2011; quoted in Assonne, 2013) was also favoured, commercialized, and consumed by this specific audience. The slaves' séga were songs consisting of real life stories pertaining to pain, sorrow, and desire. The sensuality of the slaves' song and dance in the intimacy of their slave camps is appropriated as voyeur amusement in the postcolony. The séga, as spectacle, engages with an audience which participates in the objectification of women as a performance of erotic display, dismissing the "souls of black folk" (Du Bois, 1903), inherent in the transmission of embodied histories in the séga. The physically evocative and 'erotic' proximity of the male singer to the dancers, who are mostly women, in the commercialized séga performance contributes to a mainstream conservative perception that the séga is vulgar, coarse, 'loose' or inappropriate. In fact, it is the performance as spectacle and commercialized commodity, which turn the séga dancers into exposed objects of display. The lived experience of intimacy and humanhood, which formed part of slaves' personal lives, is transformed into a display of sex appeal through the promotion of the séga for commercial use. At the same time, the 'coarseness' of the Creole language is also evoked by a conservative bourgeoisie to denigrate the séga.

The séga, as songs in Creole and dance performed in slaves' camps, was regenerated in the time around Mauritius' independence into the séga engazé (protest songs) from various groups associated with the leftist political movement. Despite this shift, the perpetuation of colonial ideology within both the séga and Mauritian Creole was maintained, as these traditions were vulgarized and commercialized as entertainment or elevated as national heritage. This is where decolonizing Mauritian Creole and the creative practices in the language is a necessary move, especially in light of a recent proposal by the state to erect a 'segatorium' as a living monument to the heritage of slaves' labour, resistance to colonialism, and sustained humanhood in the midst of oppression on the island. The golden era, as Harmon (2011) termed the late 1970s, was a productive time for artists seeking to regenerate creative practices such as music, theatre, the visual arts and literature in Mauritian Creole in a manner that harboured a conscious politics of decoloniality (Mignolo, 2009).

Decoloniality is articulated as a critique as well as a methodology and a set of practices in support of epistemic decolonization. It is an ongoing process of resistance against residual colonialism, such as the post-independence 'coloniality of power', which Peruvian thinker Aníbal Quijano (2008, p. 197) defines as the expansion of colonial dominance at a systemic and epistemic level. Ramon Grosfoguel (2011, p. 3), proponent of the decolonialization of knowledges, explains that the decolonial critique "is not an essentialist, fundamentalist, antiEuropean critique. It is a perspective that is critical of both Eurocentric and Third World fundamentalisms, colonialism and bourgeois nationalism." Decolonial thinking thus encompasses a set of practices of deconstruction, construction and reconstruction at the level of epistemology, historiography and ideology. In this sense, creative practices in Mauritian Creole for the entertainment of francophile audiences represent a neocolonial practice as they lack a decolonial critique. Extracting a 'decolonial aesthetics' (Achinte, 2003, quoted in Mignolo \& Vázquez, 2013) from the séga thus makes visible the colonial ideologies imposed upon it. Decolonial aesthetics "refers to ongoing artistic projects responding and delinking from the darker side of imperial globalization" (Decolonial aesthetics (I), 2011) and 'contributes to making visible decolonial subjectivities at the confluence of popular practices of re-existence, artistic installations, theatrical and musical performances, literature and poetry, sculpture and other visual arts' (Mignolo and Vázquez, 2013). 


\section{G. Pyndiah}

Grup Soley Ruz, was the first cultural group (Assonne 2013, p. 64) to negotiate a decolonial politics through the séga engazé, regrouping Creoles and Indo-Mauritians who shared Mauritian Creole, as mother tongue. Micheline Virahsawmy and Rosemay Nelson, two women singing in a male-dominated circle, were central figures in the group (also consisting of Bam Cuttayen, Nitish and Ram Joganah, and Lelou Menwar). They revolutionized the séga with their active militancy, using Mauritian Creole as a language of protest against neocolonial and hegemonic practices on the island. The lyrics of 'Fam lespoir' (Micheline Virahsawmy, quoted in Assonne, 2013, p. 72) subvert the colonial appropriation of Mauritian Creole as well as the séga's entertaining rhythmic 'erotic' side (promoted mostly for a European audience) by reclaiming the resistance and personhood inherent in it:

\section{$\underline{\text { Mauritian Creole }}$}

Fam lespoir

Kan to trouv lager

Amenn la mizer

Pe masakre bann inosan

Bann dirigeants napa konsian

To konn to leker

Kone to sinser

Fam avek to koudme mo sir

Nou lavenir li pou meyer

Si donn twa lokazion

Inpe pouvoir decision

\section{$\underline{\text { English translation }}$}

Women of Hope

When I see that wars

Bring poverty

And innocent people are massacred

By unscrupulous leaders

You know your heart

knows you're genuine

With your help, women, I am convinced

Our future will be better

If only you were given more opportunities

For decision making

(Micheline Virahsawmy, quoted in Assonne 2013, p. 72).

In this song, Micheline Virahsawmy denounces the patriarchal values (Assonne, 2013, pp. 6667) of wars, colonialism, and Mauritian politics and appeals to women to unite and defy the cultural hegemony on the island. Grup Soley Ruz's songs of protest are subversive to the conservative comprador bourgeoisie, made up of both Franco and Indo-Mauritian men who established the 'modern' nation-state, a result of inherited colonial structures in the postcolony. As such, the songs transmit a decolonial aesthetics which are "contesting the legacies of modernity and its re-incarnations in postmodern and altermodern aesthetics" (Decolonial aesthetics (I), 2011). The oppression of women in the postcolony is a recurrent theme in the séga engazé repertoire of the 1970s. Grup Latanier, which consists of musicians from Soley Ruz, today continues to write militant songs and produce a platform for a decolonial activism against racism, police brutality, hegemonic ideologies, government corruption and the oppression of both women and men. The séga, which was previously promoted, portrayed women as nagging, controlling, lazy, or objects of desire and made use of highly descriptive sexual connotation to entertain the audience (Assonne, 2013, p. 76). In contrast, in the lyrics of Soley Ruz, the woman is militant and empowered. 
In Grup Latanier's séga engazé 'Krapo Kriye' (quoted in Assonne, 2013, pp. 75-76), the depiction is of a conservative Hindu woman who is as much oppressed by patriarchy and the hierarchies of the postcolony as is her husband:

Mauritian Creole

Krapo Kriye

Mo mama dormi lizie ouver

Soleker bate kouma tamtam

Tann kok sante mama leve

Bizin fer vit sinon lager

Galoup lekiri li tir dite

Bann zozo ape sante

Pou donn kouraz mo ti mama

...Mo mama li esklav papa

Mo papa li esklav patron

Mo mama li enn esklav

Esklav en lot esklav

Esklav enn lot esklav

\section{$\underline{\text { English translation }}$}

Sunset croak of the grass frog

My mother sleeps with her eyes open

Her heart pounds like the tamtam beat

At the song of the cockerel, she rises

and hurries before he quarrels with her

She runs to the stable to get milk

While birds start singing

To give courage to my dear mother

...My mother is the slave of my father

My father is the slave of his master

My mother is a slave

Slave of another slave

Slave of another slave

(Group Latanier, 1981, quoted in Assonne 2013, pp. 75-76).

The neocolonial practices which continue on the plantation do not free the workers but maintain a form of slavery in which the labourer is exploited by the sugar baron and the wife is abused by the husband when he comes back home. Although indentured labour cannot be compared to slavery, which was a harsher form of epistemic exploitation, the culture and humanhood of the enslaved person and the persecution of non-white men and women in sugar plantation economies remain dominant themes of the séga engazé genre.

Decolonizing Creole entails understanding the histories of colonization which the language also bears in its inherent affective dimension. In the same vein, Mignolo's decolonial epistemologies, as methodology, proposes a different framing to knowledge-making, both in rewriting histories and in pinpointing different forms of aesthetics. Decolonial knowledges contribute to an altermodernity which is reactive to a "self-explanatory, invisible and pervasive (white-male-Christian-Western)" European modernity, which according to Mignolo (2009, p. 13), hides a darker side, coloniality. De-colonial thinking presupposes epistemically and politically de-linking from imperial foundations of knowledge, aesthetics and ideologies cast in Western imperial languages (Mignolo, 2009, pp. 18-19) and aesthetics. It is not a totalizing shift from acquired knowledge but a reframing of knowledge-making: We "know that we have to decolonize being, and to do so we have to start by decolonizing knowledge" (Mignolo, 2009, p. 13). Situating the colonial ideologies or decolonial aesthetics and politics in creative practices in Mauritian Creole is in itself a decolonial practice. 


\section{G. Pyndiah}

Creole literature requires the same analysis. In a postcolonial context, very often "in the domain of language and verbal creativity, a colonial language is 'refined' and languages without literary history are 'vulgar'. In the same way, oral texts are 'vulgar' while written texts are 'refined"' (Cooper, 1985, p. 8). Before Mauritius' independence, in the literary field, poetry in Creole was written by and for the Franco-Mauritians and "relied mainly on a French poetic model and the burlesque" (Mooneeram, 2009, pp. 50-51). Colonial poetry, from François Chrestien's Les Essais d'un bobre africain to Charles Baissac's Le Folklore de l'île Maurice, "had the function of amusement for a francophone elite comfortably conscious of its own cultural and linguistic superiority" (Mooneeram, 2009, p. 51), following the same prejudice attributed to the séga. Therefore, the history of Creole literature, starting with colonial poetry, as positioned by other linguists and historians on the island, is a perpetuation of colonial ideologies. Colonial residues have distorted the view of postcolonial realities and alienated the ex-colonized from itself, through the language of adoption (Ngũgĩ, 1986) and its derivatives. A dominant linguistic ideology occurs by choice or coercion (Derrida, 1998, p. 32) but "tends to be a response to or consequence of conditions of acute social inequality and symbolic domination" (Paugh, 2012, pp. 2-3). Decolonizing Creole entails the sustenance of colonial histories while delinking knowledge, aesthetics and ideologies at an epistemic level. In this sense, the knowledges inherent in a creole's orality and embodied histories can potentially be ascribed to its written aspect. The language debate and resistance to the use of a 'harmonized' orthography for Mauritian Creole, despite a fair degree of flexibility and the admission of it being an experimental orthography (Hookoomsingh, 2004), continue to be voiced. This echoes Virahsawmy's analysis of the colonial appropriation of Mauritian Creole:

To understand my tactical decisions, remember that one of my constant preoccupations is to protect Morisien from the franco/francophone/francophile stranglehold. Francophile 'scholars' wanted to present our language as a mere excrescence of French and presented it as a regional variation of Bourbonnais [from La Réunion, called Bourbon under French colonial rule, where Mauritian Creole seemed to have originated] pidgin. I argued with them that even if MC [Mauritian Creole] is considered as the twin of Bourbonnais, our language underwent a new process of pidginization under the influences of English and Indian languages" (Virahsawmy, 2002, quoted in Mooneeram, 2009, p. 42)

Virahsawmy focuses not only on formulating Creole orthographies but also on producing creative literary works in Mauritian Creole, with an "epistemic de-linking and epistemic disobedience" to colonial epistemologies (Mignolo, 2009, p. 17). Virahsawmy, represented as a "one-man" cultural movement (Eriksen, 1998), continues to produce a wide repertoire of literary pieces, poems, translations, communiques, newspaper articles, editorials, and academic articles written solely in Mauritian Creole. 
In this sense, as a carrier of histories embodied in 'everyday practices' which resist hegemonic discourses (De Certeau, 1998), language is also an important aspect of epistemic decolonization. Similarly, in Haiti, poetry, songs, and plays were written and performed in kreyol and were "potent political weapons" (Dubois, 2012, p. 23) in facilitating connections and communities of trust between different plantations which contributed to the organization of collective forces. According to Dubois (2012, p. 17),

it was the culture of these masses, forged in bondage - the Kreyòl language, the Vodou religion, the focus on community, dignity, and self-sufficiency - that ultimately enabled them to destroy slavery and produce something in its place.

Consider, for instance, Virahsawmy's poem on the nature of Mauritian Creole itself:

\section{$\underline{\text { Mauritian Creole }}$}

Patwa grosie

Zot tou dir mwa mo koz grosie;

Mo koz patwa ek sipakwa.

Mo bizen koz sivilize;

Pa fer kouma sorti dan bwa.

Mo ti telman entimide

$\mathrm{Ki}$ mo ti koumans vinn gaga.

Enn sans enn fwa enn ti pagla Ti dir mwa aret pran traka: "Enn diaman brit dan to labous Enn zoli bizou pou akous".

\section{$\underline{\text { English translation }}$}

Rough Creole

Everyone tells me I speak rough Creole; And that I just babble in Creole

I need to speak civilized

And not imitate those who came from the woods.

I was so intimidated

That I started stuttering

Luckily, an insane person told me, once, to stop worrying: 'A rough diamond, from your mouth, will become a precious jewel'.

(Private correspondence from Dev Virahsawmy, 2013).

Although in his later poetry, such as 'Patwa grosie' above, Virahsawmy adheres to the accepted orthography, his Creole poetics are reflective of the rough, vulgar, rawness of the language, subverting the imposition of the urban francofied Creole. Dominican Patwa, according to Paugh (2012, p. 119), is considered 'rough', 'vulgar', and 'raw' and is better suited for emotional expression and transmission of embodied histories. It is also more 'commanding' and forceful than English, which was ridiculed by Creole speakers to be 'soft' or 'gentle' - like small babies and young children (Paugh, 2012, p. 119). It is, thus, necessary to contest the vulgarity of the vulgar, itself (Cooper, 1985, p. 8). In the poem, Virahsawmy evokes prejudices against the varieties, accents, rhythms and pitches in spoken rural Creole and the intimidation which people who speak 'rough' creole suffer. This also demonstrates the French imposition on and colonial appropriation of the Creole language versus the Creole which is spoken in everyday practices, particularly in rural spaces, with the most resistance to colonial cultural influence. 


\section{G. Pyndiah}

A sculptor and contemporary artist, who writes poetry in Mauritian Creole, deserves attention here. Nirmal Hurry merges installation works and poetic pieces in Mauritian Creole in an attempt to defamiliarize how his audience imagine and feel about Mauritius. He reconstitutes a sense of place and time by recasting familiar objects and images with found recycled objects and incongruous associations. Hurry writes poetry and texts in Mauritian Creole but does not ascribe to the accepted orthography of Mauritian Creole. A piece of poetry, which stands alongside a sculpture of an iconic extinct bird, the dodo, once endemic to the main island of Mauritius, is read, here, as a form of decolonial Creole poetics which adds to the discourse of 'vulgarity' of the language.

\section{$\underline{\text { Mauritian Creole }}$}

Ti couyon couma banne colon, moi dodo Mo laviande senti pis

Prend six heures pou cuit

Zordi hollandais pe gagne constipation Français pe rod solution

Anglais pé brillé l'attention

Zistoire fini

Rakonté resté

(Nirmal Hurry, 2010)

\section{$\underline{\text { English translation }}$}

I the Dodo, was as ignorant as the colonial migrant.

My meat smells

And it needs six hours to cook.

Consequently the Dutch is constipated

The French is looking for relief

While the English blows its own trumpets. While the story of history has ended, Remembering and retelling is left for us to do

The word 'couyon' means idiot in a patronizing slang, used to describe the colonial settler who drove the dodo bird to extinction. Hurry's tone is that of the commanding Creole language (Paugh, 2012, p.119). He condemns the popular perception of the bird as 'stupid', using sarcasm to suggest that the European settler, was perhaps, more ignorant for trying to eat a bird, which was not tasty in the first place. When asked why he started to write poetry in Creole, Hurry replied that he feared the degeneration of the spoken language in rural Mauritius, compared to the embourgeoisement of francofied enunciation (Pyndiah, 2010). He remembers his school days when he would be persuaded to speak in Creole, despite the fact that his immediate family consisted of Bhojpuri speakers. He, moreover, dismisses the officialized orthography by writing Creole with a French lexifier, as he confesses that it forms part of his 'history' to have learned to write French grammar at school, while the language he spoke at home, Creole, was relegated to oral communication. He adds that his poetry is not meant to be read but heard. In this sense, his practice of 'vulgarizing' French is a subversion of the colonial ideology of 'proper' French or a purified Creole. Mignolo (2000, p. 245) reminds us that, 
[T] he program and project of Creoleness is not only to recognize and celebrate Creole as a language different from French, but to write and think in Creole appropriating French; hence, the epistemological potential of border thinking as a subaltern perspective in Creoleness.

\section{Conclusion}

This paper argues that certain creative practices of Mauritian Creole act as instruments of epistemic decolonization. The specificities of creole island dynamics have been positioned to show that different linguistic and colonial ideologies compete with the Creole language. This paper has highlighted the concept of epistemic decolonization and decolonial aesthetics by giving consideration to the affective characteristics which make mother tongues resistant to dominant linguistic ideologies and allow them to thrive, beyond national recognition or standardization. By analyzing creative practices in Mauritian Creole, colonial ideologies and decolonial epistemologies can be sifted out from a language which evolved from a colonial situation. This reflects the colonial ideologies, aesthetics, historiographies and epistemologies which can pervade a language that has a history of resistance against the colonial system.

This article provides the possibilities for understanding how epistemic colonization is entrenched at a societal and structural level as well as the methodologies which allow the unravelling of a decolonial aesthetics. As Cooper (1985, p. 4) reminds us, one culture's "knowledge" is too often another's "noise." This article articulates the knowledges that are forms of emancipatory epistemologies, yet are stifled as noise by a bourgeois society.

\section{References}

Amin, S. (1994). Re-reading the postwar period: An intellectual itinerary. New York: Monthly Review Press.

Anderson, B. (1983). Imagined communities: Reflections on the origin and spread of nationalism. London: Verso.

Asgarally, I. (2015). Écrits sur les langues. Port-Louis, Mauritius: Super Printing.

Assonne, S. (2013). Ségatiers. Port-Louis, Mauritius: Editions de la tour.

Bernabé, J., Chamoiseau, P., Confiant, R. \& Khyar, M. B. T. (1990). In praise of Creoleness. Callaloo, 13(4), 886-909.

Bignall, S. (2011). Postcolonial agency: Critique and constructivism. Edinburgh: Edinburgh University Press.

Boswell, R. (2006). Mauritius and le Malaise Creole: Oppression and equality in a postcolonial society. New York: Berghahn.

Boudet, C., \& Peghini, J. (2008). Les enjeux politiques de la mémoire du passé colonial à l'île Maurice. Transcontinentales, 1(6), 13-36.

Capuano, P. J. (2003). Truth in timbre: Morrison's extension of slave narrative song in 'Beloved'. African American Review, 37(1), 95-105.

Collen, L. (2007). What is Mauritius? Retrieved from http://www.lexpress.mu/article/what$\underline{\text { mauritius }}$ 


\section{G. Pyndiah}

Chaudenson, R., \& Mufwene, S. S. (2001). Creolization of language and culture. London: Routledge.

Cooper, C. (1985). Noises in the blood: Orality, gender, and the 'vulgar' body of Jamaican popular culture. Durham NC: Duke University Press.

De Certeau, M. (1998). The practice of everyday life. Berkeley CA: University of California Press.

Decolonial aesthetics (2011) Retrieved from https://transnationaldecolonialinstitute.wordpress.com/decolonial-aesthetics/

Derrida, J. (1998). Monolingualism of the other, or, the prosthesis of origin. Stanford CA: Stanford University Press.

Dubois, L. (2012). Haiti: The aftershocks of history. New York: Metropolitan.

Du Bois, W. E. D. (1903). The Souls of Black Folk. New York: Penguin.

Edensor, T., and Kothari, U. (2005). Sweetening colonialism: a Mauritian themed resort. In M. Lasansky \& B. McClaren (Eds.), Arquitectura y turismo (pp. 189-205). Barcelona: Editorial Gustavo Gili.

Eisenlohr, P. (2006). Little India: Diaspora, time, and ethnolinguistic belonging in Hindu Mauritius. Berkeley CA: University of California Press.

Eriksen, T. H. (1998). Common denominators: Ethnicity, nation-building, and compromise in Mauritius. New York: Berg.

Eriksen, T. H. (1992). Indians in new worlds: Mauritius and Trinidad. Social and Economic Studies, 1. Retrieved from http://hyllanderiksen.net/Indians.html

Fanon, F. (1963). The wretched of the earth. New York: Grove Press.

Fanon, F. (2008). Black skin, white masks. London: Pluto Press.

Forest, C. (2011) 'Memory representations of slavery and indenture in Mauritius: towards the recognition of silent heritage', in Truth and Justice Commission, 4: History, economy, society and memory (pp. 799-874). Port Louis, Mauritius: Government Press.

Glissant, E., \& Wing, B. (1997). Poetics of relation. Ann Arbor MI: University of Michigan Press.

Grosfoguel, R. (2011). Decolonizing post-colonial studies and paradigms of politicaleconomy: transmodernity, decolonial thinking and global coloniality. TRANSMODERNITY, 1(1), 1-36.

Hannerz, U. L. F. (1992). Cultural complexity: Studies in the social organization of meaning. New York: Columbia University Press.

Haring, L. (2009). From formalism to ideology: toward a creole narrative grammar. Research in African Literatures, 40(1), 156-165.

Harmon, J. (2015). Resistance, resilience and accommodation in slave and post-emancipation societies: the case of AfroKreol protest songs in Mauritius. Conference on Comparative Perspectives on Resistance, Resilience and Accommodation in slave and postemancipation societies. La Reduit: University of Mauritius.

Harmon, J. (2011) AfroKreols' quest for identity impacts on the future of Mauritian Creole. Devenir des Créoles, 7, 131-146.

Hazareesingh, K. (1977). History of Indians in Mauritius. London: Macmillan.

Hookoomsingh, V. (2004). A harmonized writing system for the Mauritian Creole Language. Port Louis, Mauritius: Ministry of Education and Scientific Research.

Hurry, N. (2010). Nirmal Hurry: A collection of works. Moka, Mauritius: MGI. 
Kothari, U., \& Wilkinson, R. (2010). Colonial imaginaries and postcolonial transformations: exiles, bases, beaches. Third World Quarterly, 31(8), 1395-1412.

Lowe, L., \& Lloyd, D. (Eds.) (1997). The politics of culture in the shadow of capital. Durham NC: Duke University Press.

Lugones, M. (2003). Pilgrimages/peregrinajes: theorizing coalition against multiple oppressions. Lanham MA: Rowman \& Littlefield.

Mbembe, A. (2001). On the postcolony. Berkeley CA: University of California Press.

Mignolo, W.D. (2000) Local histories/global designs: Coloniality, subaltern knowledges, and border thinking. 6th edn. Princeton NJ: Princeton University Press.

Mignolo, W. D. (2009). Epistemic disobedience, independent thought and decolonial freedom. Theory, Culture \& Society, 26(7-8), 159-181.

Mignolo, W., \& Vázquez, R. (2013). Decolonial Aesthesis: Colonial wounds/ decolonial healings. Retrieved from http://socialtextjournal.org/periscope_article/decolonialaesthesis-colonial-woundsdecolonial-healings/

Mintz, S. W. (1986). Sweetness and power: The place of sugar in modern history. New York: Penguin.

Mooneeram, R. (2009). From Creole to standard: Shakespeare, language, and literature in a postcolonial context. Amsterdam: Rodopi.

Morisson, T. (1993). Interview with Paul Gilroy. Small Acts: Thoughts on the Politics of Black Cultures. London: Serpent's Tail.

Mukherji, P. (2006). Vertical Horizon. Port Louis, Mauritius: MGI.

Munasinghe, V. (2001). Callaloo or tossed salad? East Indians and the cultural politics of identity in Trinidad. Ithaca NY: Cornell University Press.

Ngũgĩ, wa Thiong'o (1986) Decolonising the mind: The politics of language in African literature. Portsmouth, NH: Heinemann Educational.

Paugh, A. L. (2012). Playing with languages: Children and change in a Caribbean village. New York: Berghahn.

Pyndiah, B. (1978) Personal recording with Tifrer.

Pyndiah, G. (2010). Introduction. In Nirmal Hurry: A collection of works. Moka, Mauritius: MGI.

Quijano, A. (2008). Coloniality of power, eurocentricism, and Latin America. In M. Morana, E. Dussel, C. A. Jauregui, \& W. D. Mignolo (Eds.) Coloniality at large: Latin America and the postcolonial debate (pp. 181-224). Durham NC: Duke University Press.

Ramyead, L.P. (1985). The establishment and cultivation of modern standard Hindi in Mauritius. Port Louis, Mauritius: Mahatma Gandhi Institute

Said, E. (1993). Resistance, opposition and representation. In B. Ashcroft, G. Griffiths, \& H. Tiffin (Eds.) The Post-colonial studies reader (pp. 95-98). New York: Routledge.

Salverda, T. (2011). Embodied signs of elite distinction: Franco-Mauritians' white SkinColour in the face of change. Comparative Sociology, 10(4), 548-570.

Selvon, S. (2005). A comprehensive history of Mauritius: From the beginning to 2001. PortLouis, Mauritius: M.D.S. 
St-Hilaire, A. (2011). Kwéyòl in postcolonial Saint Lucia: Globalization, language planning, and national development. Philadelphia PA: John Benjamins.

Spivak, G. C. (2016) 'Critical Intimacy: An Interview with Gayatri Chakravorty Spivak'. Interview with Steve Paulson for $L A R B$, Retrieved from https://lareviewofbooks.org/article/critical-intimacy-interview-gayatri-chakravorty_ spivak/\#!

TJC (2011). Truth and Justice Commission, Volume 1. Port Louis, Mauritius: Government Printing. 